\title{
Review Article \\ Phytochemistry and Pharmacological Activities of Dracaena cinnabari Resin
}

\author{
Yahya S. Al-Awthan $\mathbb{D}^{1,2}$ and Omar Salem Bahattab $\mathbb{D}^{1}$ \\ ${ }^{1}$ Department of Biology, Faculty of Science, University of Tabuk, Tabuk, Saudi Arabia \\ ${ }^{2}$ Department of Biology, Faculty of Science, Ibb University, Ibb, Yemen \\ Correspondence should be addressed to Yahya S. Al-Awthan; alawthan@ut.edu.sa
}

Received 12 April 2021; Accepted 14 July 2021; Published 23 July 2021

Academic Editor: Victor Feitosa

Copyright (c) 2021 Yahya S. Al-Awthan and Omar Salem Bahattab. This is an open access article distributed under the Creative Commons Attribution License, which permits unrestricted use, distribution, and reproduction in any medium, provided the original work is properly cited.

\begin{abstract}
Dracaena cinnabari (D. cinnabari) is an endemic plant located in Socotra Island, Yemen. Deep red resin attained from different plant species including D. cinnabari is commonly known as dragon's blood. In folk medicine, it is prescribed for the treatment of traumatic dermal, dental, and eye injuries as well as blood stasis, pain, and gastrointestinal diseases in humans. Numerous studies have investigated that this resinous medicine has antidiarrheal, antiulcer, antimicrobial, antiviral, antitumor, antiinflammatory, analgesic, wound healing, and antioxidant activity. Several phytochemicals have been isolated from D. cinnabari, including the biflavonoid cinnabarone, triflavonoids, metacyclophanes, chalcones, chalcanes, dihydrochalcones, sterols, and terpenoids. The present review highlights the structures and bioactivities of main phytochemicals isolated from $D$. cinnabari regarding the botany and pharmacological effects of the resin derived from this plant.
\end{abstract}

\section{Dracaena cinnabari: An Overview}

1.1. Genus Dracaena. Genus Dracaena belongs to the family Agavaceae and contains xeromorphic species distributed in the Macaronesian islands, Madagascar, and along the African coast from Southern Africa into Arabia. Species of Dracaena include small much-branched trees or shrubs that are mostly deciduous and generally thorny. This genus is comprised of about 100 species in tropical and subtropical areas and produces a red resin from the sap [1]. The chloroplast genome of some species has recently been shown to be a "barcode" for Dracaena sp. identification [2].

1.2. Dracaena Resin: Dragon's Blood. It is a deep red resinous exudate that is acquired from cut stems of several species of genera Pterocarpus, Dracaena, Croton, and Daemonorops [3]. Six Dracaena plants growing in the Arabian Peninsula, Southeast Asia, and West Africa are main sources of this resin [4]. The resin is a commercially important export, especially from Socotra Island, Yemen, where it is known locally as Dam Alakhwin [5], and has been used in traditional med- icine for the treatment of wounds, fractures, ulcers, dysentery, tumors, diarrhea, and diabetes $[1,2]$. Recently, this resin was documented to have antioxidant and antiinflammatory activity that promotes and enhances skin repair, blood circulation, immune function, and hemostasis $[1,6]$. All of these effects are thought to be a result of the presence of many phenolic compounds, such as flavonoids, saponins, and terpenes, present in the resin [1]. In addition to its pharmaceutical uses, this resin has also been introduced as an art pigment by many cultures [2].

1.3. Plant Distribution. Dracaena cinnabari (D. cinnabari) is endemic to Socotra Island [7] and has been listed as a vulnerable species in Yemen according to the International Union for Conservation of Nature Red List [8]. This plant is found mostly in the highlands and mountains of central and eastern parts of the island at altitudes from 323 to $1483 \mathrm{~m}$ above sea level and missing from seaside plains and lowlands below $180 \mathrm{~m}$ above sea level [9]. In Yemen, D. cinnabari occupies only $5 \%$ of its current potential habitat according to Attorre et al. [10]. 
1.4. Botanical Description. D. cinnabari is usually 30-60 feet tall and has a straight or branched, strong trunk that is about $30 \mathrm{~cm}$ in diameter $[11,12]$. Leaves are only found at the end of the youngest branches and are shed every 3 or 4 years before new leaves simultaneously mature. A distinctive growth habit is associated with Dracaena species that is known as "dracoid habitus" [13]. The flowers are found in clusters of 2-5 and carried on racemes or panicles. Its fruits are small fleshy berries containing 1-4 seeds that change their color turn from green to orange on ripening [14]. Average weight of a seed is $68 \mathrm{mg}$, and its diameter ranges from 4 to $5 \mathrm{~mm}$ [12]. The dragon's blood tree is most famous for the blood-red sap that oozes out of it when cut or injured [15]. Photos of the plant and its resinous material (dragon's blood) are shown in Figure 1.

\section{Phytochemistry}

Phytochemical studies of $D$. cinnabari have led to the isolation of a number of flavonoids [16, 17], biflavonoids [18, 19], a series of sterols and triterpenoids [20], and triflavonoids [21].

2.1. Flavonoids. The resin of $D$. cinnabari contains several flavonoids [16, 17], including 7-hydroxy-3-(3-hydroxy-4methoxybenzyl)chroman (1); 7-hydroxy-3-(4-hydroxybenzyl)-8-methoxychroman (2); 3-(4-hydroxybenzyl)-8methyl-enedioxychroman (3); 7-hydroxy-3-(4- hydroxybenzyl)chroman (4); 7,4' -dihydroxy-3 '-methoxyflavan (5); 7,3' -dihydroxy-4 ${ }^{\prime}$-methoxyflavan (6); 7-hydroxyflavan (7); 4hydroxy-2-methoxydihydrochalcone (8); 4,4' -dihydroxy-2methoxydihydrochalcone (9); 4,4'-dihydroxy-2' -methoxychalcone (10); 7,4' -dihydroxyflavone (11); and 7-hydroxyflavan-4-one (12). The structures of these compounds have been elucidated by spectroscopic methods and are shown in Figure 2. In addition, the flavonoid $2^{\prime}, 4,4^{\prime}$-trihydroxychalcone (13), determined by Nuclear Magnetic Resonance (NMR) spectroscopy, was isolated as yellow needles for the first time via column chromatography of the $D$. cinnabari fraction [22]. This flavonoid was also isolated from $D$. cochinchinensis and is known as isoliquiritigenin [23, 24]. Sun et al. [25] have reported the presence of 13, 3, and 20 different types of chalcones, chalcanes, and dihydrochalcones, respectively. Among dihydrochalcones, loureirin A and B are considered as indicators for quality control of dragon blood from D. cinnabari [26]. Ethyl acetate extract of $D$. cinnabari resin has been identified for the presence of dracidione, a chalcone- dihydrochalcone dimer [27].

2.2. Biflavonoids. Previous phytochemical studies of D. cinnabari have led to isolation of many bioflavonoids. The biflavonoids $2^{\prime}$-methoxysocotrin $-5^{\prime}$-ol, socotrin $-4^{\prime}-\mathrm{ol}$, and homoisosocotrin $-4^{\prime}$-ol were previously isolated from $D$. cinnabari resin, and their structures elucidated mainly by NMR [18]. The recently isolated and identified biflavonoid cinnabarone (14) [19] is composed of a dihydrochalcone and a deoxotetrahydrochalcone moiety connected by a C-C bond. Its structure was determined by NMR and is outlined below.
2.3. Triflavonoids and Metacyclophanes. The triflavonoid damalachawin (15) in dragon's blood comprises a flavan and two deoxotetrahydrochalcone moieties [21]. It mainly differs from cinnabarone by replacement of the keto group by a 7-hydroxyflavan-6-yl group and a hydrogen atom. Its structure was identified by NMR as outlined below (Figure 2). In addition, metacyclophanes (dracophane) have also been identified in dragon's blood resin [28].

2.4. Sterols and Terpenoids. A total of 13 terpenoids, namely, $\alpha$-Thujene, $\alpha$-Pinene, Camphene, $\beta$-Pinene, $\delta$-3-Carene, $\mathrm{p}$ Cymene, Limonene, (-)-Isodauca-6,9-diene, $\gamma$-Elemene, trans-Muurola-3,5-diene, $\gamma$-Humulene, $\gamma$-Himachelene, and $\omega$-Amorphene were reported to be present in resins of $D$. cinnabari [29]. Likewise, Masaoud et al. [20] isolated and identified sterols and triterpenoids present in the resin of $D$. cinnabari. They reported that the resin of this plant contains cholesterol, lupeol, Cholest-4-en-3-one, stigmastanol, betulin, campesterol, $4 \alpha$-methylcholest-7-en-3 $\beta$-ol, 24 -methylenecycloartanol, 31-norcycloartanol, stigmast-22-en-3 $\beta$-ol, $4 \alpha, 14 \alpha$-dimethylcholest- 8 -en-3 $\beta$-ol, cycloartanol, sitosterol, lanost-7-en-3 $\beta$-ol, and stigmasterol [20].

\section{Traditional Uses}

D. cinnabari resin has been traditionally used for a long time in folk medicine as an analgesic, astringent, antiseptic, hemostatic, and antiulcer remedy; to treat diarrhea, fevers, fractures, and burns; and as an abortifacient, if taken during the first trimester of pregnancy $[30,31]$. In Socotra, D. cinnabari (resin) has also been traditionally used as a therapeutic agent for the treatment of GIT (gastrointestinal tract), skin, eye, and dental diseases [5]. Since centuries, it has been used as a colorant in artworks as found in paints of various ancient reverse glass paintings [15].

\section{Pharmacological Effects}

D. cinnabari resin is characterized by the presence of different bioactive flavonoids, which are responsible for its wide pharmacological effects [32]. Al-Afifi et al. [33] reported the tolerability of a methanol extract of $D$. cinnabari resin administered to rats included dosages up to $1500 \mathrm{mg} / \mathrm{kg}$ daily for 28 days without any toxic effects.

4.1. Hemostasis and Wound Healing. The hemostatic potency of $D$. cinnabari resin is found to be effective against external and internal injuries [5]. There are no scientific studies that demonstrate the exact mechanism by which this resin exerts its wound healing activity; however, wound healing formula containing the resin was patented [34].

Many authors have evaluated the wound healing activity of Dracaena species resin using animal models. For example, the ethanolic extract of $D$. cochinchinensis resin showed antithrombotic and anticoagulation activities in rats [31]. Likewise, Liu et al. [35] demonstrated that rats that received an ethanolic extract of $D$. cochinchinensis resin showed significantly better wound contraction and skin-breaking strength compared with the control group. These results highlight the significance of dragon's blood resin in the reduction of 


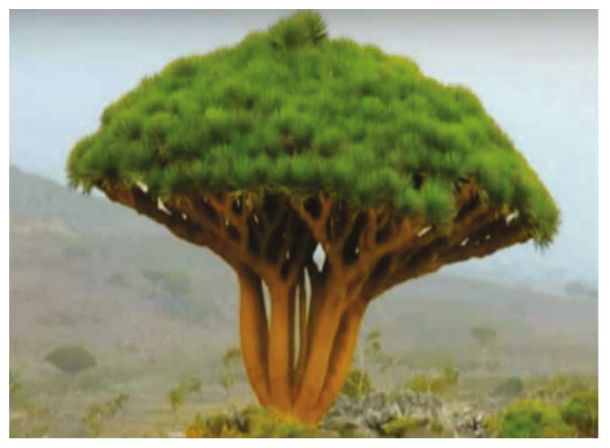

(a)

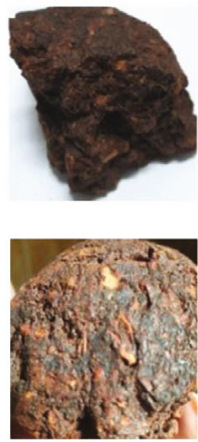

(b)

Figure 1: Photos of D. cinnabari (a) and its resin collected for marketing purposes (b).

clotting time. Other in vitro studies have shown an inhibitory effect of three (loureirin B, cochinchinenin A, and $3,4^{\prime}$ -dihydroxy-5-methoxystilbene) compounds isolated from dragon's blood on ADP-induced platelet aggregation [36, 37]. In addition, a clinical trial conducted by Namjoyan et al. [38] suggested that dragon's blood resin from Croton lechleri is a potent, affordable, and safe healing agent.

4.2. Antidiabetic and Hypolipidemic Effects. The resin of D. cinnabari has been shown to have high antidiabetic activity through standard glucose uptake procedures against MCF-7 cell lines in vitro [39]. Similarly, Al-Baoqai et al. [40] demonstrated that an ethanolic extract of D. cinnabari resin (100 and $300 \mathrm{mg} / \mathrm{kg}$ ) has hypoglycemic and hypolipidemic activity in alloxan-induced diabetic rats. In vitro assay of the hypolipidemic effects of another D. cinnabari resin extract has inhibition potential against pancreatic lipase, malate dehydrogenase, and glucose-6-phosphate dehydrogenase [41]. Furthermore, a newly C-linked chalconedihydrochalcone dimer, named dracidione, isolated from the $D$. cinnabari resin is reported to have moderate $\alpha$-glucosidase inhibitory activity, with a half-maximal inhibitory concentration of $40.27 \mu \mathrm{g} / \mathrm{mL}$ [28]. These results indicate $D$. cinnabari resin has hypoglycemic and antihyperlipidemic effects that can play a role in the treatment of diabetes.

4.3. Antimicrobial Effects. Natural products of different higher plants have been reported to be good sources of antimicrobial agents [42]. The first preliminary investigations to show the antimicrobial activity of $D$. cinnabari resin extracts were done by Mothana and Lindequest [43] and Taleb et al. [44]. Also, a dichloromethane extract of $D$. cinnabari resin has been found to have good inhibitory activity against various food-borne pathogens using an agar disc diffusion method [45]. In addition, the antimicrobial activities of different solvent (chloroform, methanol, and benzene) extracts of D. cinnabari resin against Gram-positive bacteria, Gramnegative bacteria, and fungi revealed that these microorganisms have varied sensitivity to the different extracts $[46,47]$. Similarly, Altwair and Edrah [48] have reported that aqueous and ethanolic extracts of $D$. cinnabari significantly inhibited the activity of E. coli ( $13 \& 14 \mathrm{~mm})$, P. vulgaris (9 and $10 \mathrm{~mm}$ ), $P$. aeruginosa (8 and $9 \mathrm{~mm}), K$. pneumonia (7 and
$8 \mathrm{~mm}$ ), and S. saprophyticus (10 and $11 \mathrm{~mm}$ ), respectively. Antimicrobial assays have been performed to assess the effect of $D$. cinnabari's resin extracts against $B$. subtilis, $S$. aureus, M. luteus, S. flexneri, S. enteritidis, P. mirabilis, E. areogenes, E. coli, $P$. aeruginosa, C. albicans, and A. flavus. Purposely, $\mathrm{CH}_{2} \mathrm{Cl}_{2}$ extract of dragon's blood resin revealed maximum antimicrobial potential against all the tested bacterial and fungal strains except Salmonella enteritidis [45]. The methanolic extract of $D$. cinnabari also showed antiviral effects against influenza virus $\mathrm{A}$ and herpes simplex virus with IC $_{50}$ values $1.5 \mu \mathrm{g} / \mathrm{mL}$ and $12.5 \mu \mathrm{g} / \mathrm{mL}$, respectively [49]. The previous documented antimicrobial activity of aqueous and ethanolic extract of D. cinnabari may be due primarily to the presence of flavonoids and their antioxidant activity.

4.4. Anti-Inflammatory and Analgesic Effects. Alwashli et al. [50] evaluated the anti-inflammatory and analgesic activities of an ethanolic extract of $D$. cinnabari resin using animal models and found that it significantly reduced inflammation at 50 and $150 \mathrm{mg} / \mathrm{kg}$ oral doses. In lipopolysaccharidestimulated mouse macrophage cell line RAW 264.7, methanolic extract of $D$. cinnabari resin and its bioactive component ( $4^{\prime}$-hydroxy-7,8-methylenedioxyhomoisoflavan) have shown inhibitory effect on nitrite, tumor necrosis factor- $\alpha$, and interleukin- 6 production. Reduction in rat edema also validated the anti-inflammatory potential of experimented treatments. These results suggest that $D$. cinnabari resin has important anti-inflammatory effects at selected doses [51]. In addition, compounds isolated and purified from a crude hexane extract of $D$. cinnabari resin were also shown to have anti-inflammatory activity [52].

4.5. Enhancing Immune Function. The immune system is a highly complex system with both innate and acquired responses that may be altered by certain biological or pharmacological components; such alteration of immune response is referred as immunomodulating activity [53]. To date, no published research articles have investigated the effect of $D$. cinnabari resin on immune system activity. However, one study conducted on female mice showed that administration of dragon's blood $(0.072 \mathrm{~g} / \mathrm{kg})$ significantly elevates spleen weight [54]. Furthermore, microscopic examination revealed an enlarged follicular germinal center with a 
<smiles>[R]C1=C([R])C2OCC(Cc3ccc([R])c([R])c3)C[C@H]2C=C1</smiles><smiles>[R]C1=CC2OC(c3ccc([R])c([R])c3)CCC2C=C1</smiles>

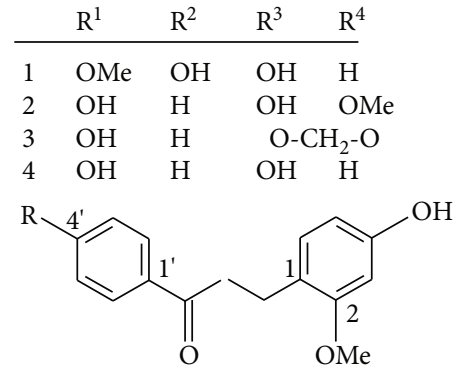

$8 \mathrm{R}=\mathrm{H}$

$9 \mathrm{R}=\mathrm{OH}$

\begin{tabular}{llll} 
& $\mathrm{R}^{1}$ & $\mathrm{R}^{2}$ & $\mathrm{R}^{3}$ \\
\hline 5 & $\mathrm{OH}$ & $\mathrm{OMe}$ & $\mathrm{OH}$ \\
6 & $\mathrm{OMe}$ & $\mathrm{OH}$ & $\mathrm{OH}$ \\
7 & $\mathrm{H}$ & $\mathrm{H}$ & $\mathrm{OH}$
\end{tabular}<smiles>COc1cc(O)ccc1C(=O)/C=C/c1ccc(O)cc1</smiles>

10<smiles>O=c1cc(-c2ccc(O)cc2)oc2cc(O)ccc12</smiles>

11<smiles>O=C1CC(c2ccccc2)Oc2cc(O)ccc21</smiles>

12<smiles>O=C(/C=C/c1ccc(O)cc1)c1ccc(O)cc1O</smiles>

13<smiles>COc1ccc(OC)c(CCC(c2ccc(O)cc2)c2cc(CCC(=O)c3ccc(O)cc3)c(O)cc2OC)c1</smiles>

14<smiles></smiles>

15

FIGURE 2: Structures of compounds isolated from D. cinnabari resin cleared up by spectroscopic methods.

significant increase in plasma, giant, and reticular cell number in the medullary cord of the spleen. These results indicate the importance of dragon's blood in the enhancement of the immune system.

4.6. Antispasmodic and Relaxant Effects. The aqueous extract of $D$. cinnabari resin has been shown to cause a concentration-dependent decrease of amplitude in phasic contractions. In albino male rats, it relaxes the tone of longitudinal segments of the ileum, uterus, and urinary bladder rings [30]. This observation is consistent with the reported effects of other Dracaena species and dragon's blood-producing plants. The relaxant effect of the $D$. cinnabari resin aqueous extract may be attributed to the presence of hydrophilic flavonoids in the resin since different flavonoids have been shown to exert spasmolytic effects on smooth muscles of different preparations [55]. Following this report, there have been no other publications investigating the relaxation potential of $D$. cinnabari resin extracts except for a registered patent of wound healing formula containing the resin [34]. Meanwhile, there is a report on mice indicating that $D$. cochinchinensis resin antagonizes uterine smooth muscle contraction instigated by diethylstilbestrol [56]. 
4.7. Cardiotonic and Hypotensive Potential. The injection of an aqueous extract of $D$. cinnabari resin $\left(10^{-4}-0.03 \mathrm{mg}\right.$ ) in vivo (rat model) has been shown to increase contractility but did not significantly affect the beating rate of the isolated perfused heart of a rat. Additionally, in anesthetized rats, it revealed a hypotensive effect when intravenously injected $(0.04-12 \mathrm{mg} / \mathrm{kg})$ [30].

4.8. Anticancer, Antitumor, and Chemopreventive Potential. Various Dracaena species have been investigated for anticancer, antitumor, and chemopreventive potential. An in vitro microsomal peroxidation assay was used in the first screen of flavonoids and chalcones of $D$. cinnabari resin for antioxidant activity. Among them, 7,8-methylenedioxy-3(4-hydroxybenzyl)chromane was one tested homoisoflavonoid, which exhibited strong antioxidant activity comparable to that of the strongest flavonol antioxidant known, quercetin [57]. In the screening of Yemeni plants used in folk medicine for anticancer potential, methanolic extracts of Dendrosicyos socotrana, Withania aduensis, W. riebeckii, D. cinnabari, and Buxus hildebrandlii had the greatest anticancer activity against several tumor lines tested [43]. Alabsi et al. [58] designed a bioassay-guided fractionation approach to determine the cytotoxic and apoptosis-inducing effects of $D$. cinnabari resin on human oral squamous cell carcinoma and concluded that it has the potential to be developed as an anticancer agent. In vitro, ether and ethyl acetate extracts of $D$. cinnabari resin showed 50\% inhibition against MCF-7 breast cancer cells at $100 \mu \mathrm{g} / \mathrm{mL}$ doses [59]. A recent in vivo study revealed that administration of a methanol extract of $D$. cinnabari resin at dosages of 100,500 , and $1000 \mathrm{mg} / \mathrm{kg}$ in mice decreased the incidence of 4-nitroquinoline-1-oxide-induced oral squamous cell carcinoma compared to the induced cancer group that did not receive treatment [33]. Receipt of $1000 \mathrm{mg} / \mathrm{kg}$ extract was shown to inhibit expression of cyclin $\mathrm{D} 1, \mathrm{Ki}-67, \mathrm{Bcl}-2$, and $\mathrm{p} 53$ proteins as well as induce apoptosis by the upregulation of Bax and Casp3 and downregulation of Tp53, Bcl-2, Cox-2, cyclin D1, and EGFR [34]. According to the finding of an in vitro study, the methanolic D. cinnabari resin extract induced apoptosis and other cytotoxic effects in H103 tongue squamous cell carcinoma cells in a dose- and timedependent manner. Methanolic extract of dragon's blood resin has shown a significant cytotoxic effect in $\mathrm{H} 103$ cells, while low cytotoxicity was observed in the case of normal cells. In experimented tongue squamous cell carcinoma cells (H103), methanolic extract of $D$. cinnabari resulted in morphological changes, induction of apoptotic conditions, and cell cycle arrest ( $\mathrm{S}$ and $\mathrm{G} 2 / \mathrm{M}$ phase). It was noticed that the incidence of squamous cell carcinoma in induced oral cancer was 85.7\%; however, groups that were administrated with methanolic extract $\left(100,500\right.$, and $\left.100 \mathrm{mg} \mathrm{kg}^{-1}\right)$ of dragon's blood resin were $57.1 \%, 28.6 \%$, and $14.3 \%$, respectively [60]. They further stated that this anticancer effect of D. cinnabari may be due to inhibition of p-53, Cox-2 Bcl-2, and cyclin D1 expression and upregulation of Casp-3 and Bax genes [61].

\section{Conclusions}

Here, the botanical source, phytochemistry, flavonoid content, and pharmacological effects of dragon's blood resin from Yemeni $D$. cinnabari plants were reviewed. Information was collected from 61 published articles studying different aspects of dragon's blood resin. The main chemical constituents of $D$. cinnabari resin are flavonoids, which have been demonstrated to have significant blood circulation, hemostasis, muscle relaxation, analgesic, and anticancer effects. Interestingly, D. cinnabari resin from Socotra Island has been shown to have more powerful effects than other imported ones available in local Yemeni markets. Studies on various cell lines and animal modeling must be carried out to validate the pharmacological properties of bioactive compounds within the resin. Further investigations regarding volatile metabolites of the resin should also be conducted due to the limited number of current reports on this topic.

\section{Conflicts of Interest}

The authors declare no conflict of interest.

\section{Acknowledgments}

The authors thank Dr. Anees Ahmed Khalil, University Institute of Diet and Nutritional Sciences, Faculty of Allied Health Sciences, the University of Lahore, Pakistan, for his great help and efforts during the preparation and collection of research materials.

\section{References}

[1] Z. M. Thu, K. K. Myo, H. T. Aung, C. Armijos, and G. Vidari, "Flavonoids and stilbenoids of the genera Dracaena and Sansevieria: structures and bioactivities," Molecules, vol. 25, no. 11, p. $2608,2020$.

[2] Z. Zhang, Y. Zhang, M. Song, Y. Guan, and X. Ma, "Corrigendum: Species identification of Dracaena using the complete chloroplast genome as a super-barcode," Frontiers in Pharmacology, vol. 11, p. 51, 2020.

[3] D. Gupta, B. Bleakley, and R. K. Gupta, "Dragon's blood: Botany, chemistry and therapeutic uses," Journal of Ethnopharmacology, vol. 115, no. 3, pp. 361-380, 2008.

[4] J. Sun, J. N. Liu, B. Fan et al., "Phenolic constituents, pharmacological activities, quality control, and metabolism of Dracaena species: A review," Journal of Ethnopharmacology, vol. 244, pp. 112138-112444, 2019.

[5] M. Al-Fatimi, "Ethnobotanical survey of Dracaena cinnabari and investigation of the pharmacognostical properties, antifungal and antioxidant activity of its resin," Plants, vol. 7, no. 4, p. 91, 2018.

[6] B. M. Silva, R. P. Santos, L. S. Mendes et al., "Dracaena draco L. fruit: Phytochemical and antioxidant activity assessment," Food Research International, vol. 44, no. 7, pp. 2182-2189, 2011.

[7] A. G. Miller, M. Morris, A. Diccon, and R. Atkinson, Ethnoflora of the Soqotra Archipelago, Royal Botanic Garden Edinburgh, Edinburgh, 2004.

[8] IUCN, "IUCN Red List of Threatened Species," 2019, Version 2019.3.February 2020, http://www.iucnredlist.org.

[9] P. Maděra, D. Volařík, Z. Patočka et al., "Sustainable land use management needed to conserve the dragon's blood tree of Socotra island, a vulnerable endemic umbrella species," Sustainability, vol. 11, no. 13, 2019. 
[10] F. Attorre, F. Francesconi, N. Taleb et al., "Will dragonblood survive the next period of climate change? Current and future potential distribution of Dracaena cinnabari (Socotra, Yemen)," Biological conservation, vol. 138, no. 3-4, pp. 430439, 2007.

[11] U. Eggli, Illustrated Handbook of Succulent Plants: Monocotyledons, Springer Berlin Heidelberg, Berlin, 2001.

[12] R. Adolt and J. Pavlis, "Age structure and growth of Dracaena cinnabari populations on Socotra," Trees, vol. 18, no. 1, pp. 43-53, 2004.

[13] J. J. Bos, Dracaena in West Africa, [Ph.D. thesis], Agricultural University Wageningen, 1984, https://edepot.wur.nl/162504.

[14] I. A. Ibraheam, H. M. Hussein, and I. H. Hameed, "Bioactivities, characterization, and therapeutic uses of Dracaena cinnabari," International Journal of Pharmaceutical Quality Assurance, vol. 9, no. 1, 2018.

[15] U. Baumer and P. Dietemann, "Identification and differentiation of dragon's blood in works of art using gas chromatography/mass spectrometry," Analytical and Bioanalytical Chemistry, vol. 397, no. 3, pp. 1363-1376, 2010.

[16] V. Suchy, B. Bobovnick'y, J. Troj'anek, M. Bud`es'in`sk'y, and K. Ubik, "Homoisoflavans and other constituents of dragon's blood from Dracaena cinnabari," in Progress on Terrestrial and Marine Natural Products of Medicinal and Biological Interest, J. M. Pezzuto, Ed., pp. 110-118, American Botanical Council, Austin, 1991.

[17] M. Masaoud, H. Ripperger, A. Porzel, and G. Adam, "Flavonoids of dragon's blood from Dracaena cinnabari," Phytochemistry, vol. 38, no. 3, pp. 745-749, 1995.

[18] M. Masaoud, U. Himmelreich, H. Ripperger, and G. Adam, "New biflavonoids from dragon's blood of Dracaena cinnabari," Planta Medica, vol. 61, no. 4, pp. 341-344, 1995.

[19] M. Masaoud, H. Ripperger, U. Himmelreich, and G. Adam, "Cinnabarone, a biflavonoid from dragon's blood of Dracaena cinnabari," Phytochemistry, vol. 38, no. 3, pp. 751-753, 1995.

[20] M. Masaoud, J. Schmidt, and G. Adam, "Sterols and triterpenoids from Dracaena cinnabari," Phytochemistry, vol. 38, no. 3, pp. 795-796, 1995.

[21] U. Himmelreich, M. Masaoud, G. Adam, and H. Ripperger, "Damalachawin, a triflavonoid of a new structural type from dragon's blood of Dracaena cinnabari," Phytochemistry, vol. 39, no. 4, pp. 949-951, 1995.

[22] Y. S. Al-Awthan, S. Abdalla, and M. Abu-Zarga, Effects of selected chemical ingredients from Dracaena cinnabari on rat isolated smooth muscles, blood pressure, perfused heart and diuresis, [Ph.D. thesis], Jordan University, Amman, Jordan, 2003.

[23] Z. Zhou, J. Wang, and C. Yang, "Cochinchinenin new chalcone dimer from Chinese dragon blood," Yaoxue Xuebao, vol. 36, no. 3, pp. 200-204, 2001.

[24] J. W. Wegener and H. Nawrath, "Differential effects of isoliquiritigenin and YC-1 in rat aortic smooth muscle," European Journal of Pharmacology, vol. 323, no. 1, pp. 89-91, 1997.

[25] J. Sun, Y. Song, H. Sun et al., "Characterization and quantitative analysis of phenolic derivatives in Longxuetongluo Capsule by HPLC-DAD-IT-TOF-MS," Journal of pharmaceutical and biomedical analysis, vol. 145, pp. 462-472, 2017.

[26] C. Wu, X. Q. Cai, Y. Chang et al., "Rapid identification of dragon blood samples from Daemonorops draco, Dracaena cinnabari and Dracaena cochinchinensis by MALDI-TOF mass spectrometry," Phytochemical Analysis, vol. 30, no. 6, pp. $720-726,2019$.

[27] I. E. Helal, M. Elsbaey, A. M. Zaghloul, and E. S. S. Mansour, "A unique C-linked chalcone-dihydrochalcone dimer from Dracaena cinnabari resin," Natural product research, vol. 7, pp. 1-6, 2019.

[28] D. Veselá, R. Marek, K. Ubik, K. Lunerová, VÆ. Sklenář, and V. Suchý, "Dracophane, a metacyclophane derivative from the resin of Dracaena cinnabari Balf.," Phytochemistry, vol. 61, no. 8, pp. 967-970, 2002.

[29] L. Vaníčková, A. Pompeiano, P. Maděra, T. J. Massad, and P. Vahalík, "Terpenoid profiles of resin in the genus Dracaena are species specific," Phytochemistry, vol. 170, 2020.

[30] Y. S. Al-Awthan, M. Abu Zarga, and A. Abdalla, "Flavonoids content of Dracaena cinnabari resin and effects of the aqueous extract on isolated smooth muscle preparations, perfused heart, blood pressure and Diuresis in the rat," Jordan Journal of Pharmaceutical Sciences, vol. 3, no. 1, 2010.

[31] N. Xin, Y. J. Li, Y. Li et al., “Dragon's blood extract has antithrombotic properties, affecting platelet aggregation functions and anticoagulation activities," Journal of Ethnopharmacology, vol. 135, no. 2, pp. 510-514, 2011.

[32] P. Maděra, A. Forrest, P. Hanáček et al., "What we know and what we do not know about dragon trees?," Forests, vol. 11, no. 2, p. 236, 2020.

[33] N. A. Al-Afifi, A. M. Alabsi, M. M. Bakri, and A. Ramanathan, "Acute and sub-acute oral toxicity of Dracaena cinnabari resin methanol extract in rats," BMC Complementary and Alternative Medicine, vol. 18, no. 1, p. 50, 2018.

[34] A. E. Al-Terki, "Wound healing composition," US Patent US9295700B1, 2016.

[35] H. Liu, S. Lin, D. Xiao, X. Zheng, Y. Gu, and S. Guo, "Evaluation of the wound healing potential of Resina Draconis (Dracaena cochinchinensis) in animal models," Evidence-Based Complementary and Alternative Medicine: eCAM, vol. 2013, article 709865, 10 pages, 2013.

[36] Y. M. Xu and X. F. Su, "Advances in studies on Guangxi Dracaena cochinchinensis," Nan Ning Shi Fan Gao Deng Zuan Ke Xue Xiao Xue Bao, vol. 24, pp. 140-141, 2007.

[37] T. B. Zhang, J. C. Lv, K. L. Yong, L. R. Xu, and X. Chen, "Effect of chemical constituents of Dracaena cochinchinenesis on platelet aggregation," Natural Product Research \& Development, vol. 20, pp. 695-697, 2008.

[38] F. Namjoyan, F. Kiashi, Z. B. Moosavi, F. Saffari, and B. S. Makhmalzadeh, "Efficacy of Dragon's blood cream on wound healing: A randomized, double-blind, placebo-controlled clinical trial," Journal of traditional and complementary medicine, vol. 6, no. 1, pp. 37-40, 2016.

[39] Y. H. Mohammed and S. A. Khanum, "Antidiabetic activity of Dracaen cinnabari Balf. F extracts from resin in Socotra Island-Yemen," Plant biochemistry \& physiology, vol. 4, no. 1, 2016.

[40] N. al-Baoqai, H. al-Mahbashi, and A. al-Adhal, "Antidiabetic and antihyperlipidemic activity of Dracaena cinnabari Balf. resin ethanolic extract of Soqatra Island in experimental animals," Universal Journal of Pharmaceutical Research, vol. 3, 2018.

[41] Y. H. E. Mohammed, D. Hs, F. H. Al-Ostoot, Zabiulla, Anilakumar, and S. A. Khanum, "In vitro evaluation of hypolipidemic effect of extracts of medicinal Dracaena cinnabari Balf. f. resin," Asian Journal of Pharmaceutical and Clinical Research, vol. 20, no. 10, pp. 118-120, 2019. 
[42] B. Khameneh, M. Iranshahy, V. Soheili, and B. S. Fazly Bazzaz, "Review on plant antimicrobials: a mechanistic viewpoint," Antimicrobial Resistance \& and Infection Control, vol. 8, no. 1, pp. 1-28, 2019.

[43] R. Mothana and U. Lindequist, "Antimicrobial activity of some medicinal plants of the island Soqotra," Journal of Ethnopharmacology, vol. 96, no. 1-2, pp. 177-181, 2005.

[44] M. Taleb, B. Svobodova, I. Langrova, and L. Kokoska, "Antimicrobial activity of some Yemeni medicinal plants," Planta Medica, vol. 73, no. 9, p. 134, 2007.

[45] D. Gupta and R. K. Gupta, "Bioprotective properties of dragon's blood resin: in vitro evaluation of antioxidant activity and antimicrobial activity," BMC Complementary and Alternative Medicine, vol. 11, no. 1, pp. 1-9, 2011.

[46] Y. Abu-Taleb, F. Ahmed, T. Kadam, and R. Shaikh, "In vitro evaluation of antimicrobial and antioxidant activity of dragon's blood tree (Dracaena cinnabari Balf.f.) of Socotra Island (Yemen)," Journal of Coastal Life Medicine, vol. 1, no. 2, pp. 123-129, 2013.

[47] M. J. Ansari, A. al-Ghamdi, N. al-Waili, N. Adgaba, K. A. Khan, and A. Amro, "Antimicrobial activity of Dracaena cinnabari resin from Soqotra Island on multi drug resistant human pathogens," Journal of Traditional Complementary \& Alternative Medicines, vol. 13, no. 1, pp. 123-127, 2016.

[48] K. Altwair and S. Edrah, "Phytochemical screening and antimicrobial activity for plants Dracaena cinnabari Verbena officinal, Polygala tenuifolia and Linux usitatissimum," Journal of Current Chemical and Pharmaceutical Sciences, vol. 5, pp. 4755, 2015.

[49] R. A. A. Mothana, R. Mentel, C. Reiss, and U. Lindequist, "Phytochemical screening and antiviral activity of some medicinal plants from the island Soqotra," Phytotherapy research, vol. 20, no. 4, pp. 298-302, 2006.

[50] A. Alwashli, M. Sobarry, Y. Cherrah, and K. Alaoui, "Antiinflammatory and analgesic effects of ethanol extract of Dracaena cinnabari Balf. as endemic plant in Yemen," International Journal of Pharmacology \& Biological Sciences, vol. 3, pp. 96-106, 2012.

[51] D. Gupta, N. Verma, H. R. Das, and R. K. Gupta, "Evaluation of anti-inflammatory activity of Dracaena cinnabari Balf. f. resin," Indian Journal of Natural Products and Resourses, vol. 5, no. 3, pp. 215-222, 2014.

[52] Y. H. E. Mohammed and S. A. Khanum, "Biological effect of extracts Dracaen Cinnabari Balf. F resin in Socotra Island (Yemen)," Journal of Bio Innovation, vol. 4, no. 5, pp. 216235, 2015.

[53] G. Sandner, M. Heckmann, and J. Weghuber, "Immunomodulatory activities of selected essential oils," Biomolecules, vol. 10, no. 8, p. 1139, 2020.

[54] X. Y. Zeng, F. He, Y. D. Li et al., "The toxicity study of analgesic and anti-inflammatory effect of Guangxi dragon's blood," China Journal of Chinese Material Medica, vol. 24, pp. 171173, 1999.

[55] A. Hazekamp, R. Verpoorte, and A. Panthong, "Isolation of a bronchodilator flavonoid from the Thai medicinal plant Clerodendrum petasites," Journal of Ethnopharmacology, vol. 78, no. 1, pp. 45-49, 2001.

[56] J. Y. Fan, T. Yi, C. M. Sze-To et al., "A systematic review of the botanical, phytochemical and pharmacological profile of Dracaena cochinchinensis, a plant source of the ethnomedicine "dragon's blood"," Molecules, vol. 19, no. 7, pp. 1065010669, 2014.

[57] M. Machala, R. Kubínová, P. Horavová, and V. Suchý, "Chemoprotective potentials of homoisoflavonoids and chalcones of Dracaena cinnabari: modulations of drug-metabolizing enzymes and antioxidant activity," Phytotherapy Research: PTR, vol. 15, no. 2, pp. 114-118, 2001.

[58] A. M. Alabsi, K. L. Lim, I. C. Paterson, R. Ali-Saeed, and B. A. Muharram, "Cell cycle arrest and apoptosis induction via modulation of mitochondrial integrity by Bcl-2 family members and caspase dependence in Dracaena cinnabari-treated H400 human oral squamous cell carcinoma," Biomed Research International, vol. 2016, Article ID 4904016, 13 pages, 2016.

[59] Y. H. E. Mohammed, "In-vitro anti-cancer activity of extracts Dracaen cinnabari Balf. F resin from Socotra Island in Yemen Republic," Biochemistry \& Analytical Biochemistry, vol. 5, no. 3, 2016

[60] N. A. Al-Afifi, A. M. Alabsi, G. Shaghayegh et al., "The in vitro and in vivo antitumor effects of Dracaena cinnabari resin extract on oral cancer," Archives of oral biology, vol. 104, pp. 77-89, 2019.

[61] N. Al-Afifi, A. Alabsi, F. Kaid, M. Bakri, and A. Ramanathan, "Prevention of oral carcinogenesis in rats by Dracaena cinnabari resin extracts," Clinical Oral Investigations, vol. 23, no. 5, pp. 2287-2301, 2019. 